$12-2013$

\title{
Conscientious objection to provision of legal abortion care
}

Brooke R. Johnson Jr

Eszter Kismödi

Monica V. Dragoman

Marleen Temmerman

Follow this and additional works at: https://ecommons.aku.edu/eastafrica_fhs_mc_obstet_gynaecol

Part of the Obstetrics and Gynecology Commons 


\title{
CONSCIENTIOUS OBJECTION
}

\section{Conscientious objection to provision of legal abortion care}

\author{
Brooke R. Johnson Jr ${ }^{a}$, Eszter Kismödi ${ }^{b}$, Monica V. Dragoman ${ }^{a}$, Marleen Temmerman ${ }^{a}$

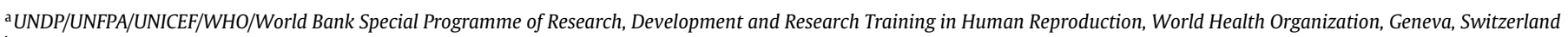 \\ ${ }^{\mathrm{b}}$ Independent International Human Rights Lawyer, Geneva, Switzerland
}

\section{A R T I C L E I N F O}

\section{Keywords:}

Abortion

Conscientious objection

Human rights

Maternal health

Women's health

\begin{abstract}
A B S T R A C T
Despite advances in scientific evidence, technologies, and human rights rationale for providing safe abortion, a broad range of cultural, regulatory, and health system barriers that deter access to abortion continues to exist in many countries. When conscientious objection to provision of abortion becomes one of these barriers, it can create risks to women's health and the enjoyment of their human rights. To eliminate this barrier, states should implement regulations for healthcare providers on how to invoke conscientious objection without jeopardizing women's access to safe, legal abortion services, especially with regard to timely referral for care and in emergency cases when referral is not possible. In addition, states should take all necessary measures to ensure that all women and adolescents have the means to prevent unintended pregnancies and to obtain safe abortion.

(c) 2013 International Federation of Gynecology and Obstetrics. Published by Elsevier Ireland Ltd. All rights reserved.
\end{abstract}

\section{Introduction}

Over the past 2 decades, the scientific evidence, technologies, and human rights rationale for providing safe abortion care have advanced considerably. Despite these advances, however, a broad range of cultural, regulatory, and health system barriers that deter access to abortion continues to exist in many countries, and the numbers and proportion of unsafe abortions continue to increase, especially in low- and middle-income countries [1]. When conscientious objection to provision of abortion becomes one of these barriers, it can create risks to women's health and their human rights.

In view of the continuing need for evidence- and human rightsbased recommendations for providing safe abortion care, WHO published the second edition of Safe Abortion: Technical and Policy Guidance for Health Systems in June 2012 [2]. In addition to providing recommendations for clinical care and service delivery, the document highlights a number of regulatory and policy barriers, including conscientious objection, and provides guidance to eliminate them. If implemented at country level, the WHO guidance provides a comprehensive framework that can have a substantive public health impact on reducing preventable abortion-related deaths and disability.

\footnotetext{
* Corresponding author: Brooke R. Johnson Jr, RHR/HRP, World Health Organization, 20 Avenue Appia, 1211 Geneva 27, Switzerland. Tel.: +41 22791 2828; fax: +41227914171.

E-mail address: johnsonb@who.int (B.R. Johnson Jr).
}

\section{What is conscientious objection to provision of abortion?}

Conscientious objection means that healthcare professionals or institutions exempt themselves from providing or participating in abortion care on religious and/or moral or philosophical grounds. While other regulatory and health system barriers also hinder women's right to obtain abortion services, conscientious objection is unique because of the tension existing between protecting, respecting, and fulfilling women's rights and health service providers' right to exercise their moral conscience. Although the right to freedom of thought, conscience, and religion is protected by international human rights law, the law stipulates that freedom to manifest one's religion or beliefs may be subject to limitations to protect the fundamental human rights of others [3]. Therefore, laws and regulations should not entitle health service providers or institutions to impede women's access to legal health services [4].

Health services should be organized in such a way as to ensure that an effective exercise of the freedom of conscience of healthcare professionals does not prevent women and adolescents from obtaining access to services to which they are entitled under the applicable legislation [2]. Based on available health evidence and human rights standards, the WHO safe abortion guidance stipulates that healthcare professionals who claim conscientious objection must refer women to a willing and trained service provider in the same or another easily accessible healthcare facility, in accordance with national law. Where referral is not possible, the healthcare professional who objects must provide safe abortion to save the woman's life and to prevent damage to her health. Furthermore, women who present with complications from an abortion, including illegal or unsafe abortion, must be treated urgently and respectfully, in the same way as any other emergency patient, without punitive, prejudiced, or biased behaviors [2]. Adherence to the individual 
and institutional responsibilities outlined in the WHO guidance allows for the exercise of moral conscience without compromising women's and adolescents' access to safe, legal abortion services if sufficient facilities, service providers, necessary equipment, and drugs are made available.

\section{Conscientious objection as a barrier to abortion care}

In theory, conscientious objection need not be a barrier to women seeking abortion. However, not all claims to conscientious objection reflect a genuine concern about compromising an individual provider's moral integrity; rather, they may represent reluctance to provide certain sexual and reproductive health services such as abortion, discriminatory attitudes, or other motivations stemming from self-interest [5]. In practice, individual or institutional refusal to provide timely referral and emergency care interferes with women's access to services and may increase health risks. In addition to limiting women's access to lawful services in general, abuse of conscientious objection can result in inequities in access, creating disproportionate risks for poor women, young women, ethnic minorities, and other particularly vulnerable groups of women who have fewer alternatives for obtaining services. Women's access to health services is jeopardized not only by providers' refusal of care but also by governments' failure to ensure adequate numbers and distribution of providers and facilities to offer abortion services.

In contexts in which conscientious objection risks harming women's health and their human rights, it is likely to coexist with a broad range of other regulatory and health system barriers, which may be intended to discourage and limit women's access to legal abortion. For example, lack of public information about safe abortion, poorly defined or narrowly interpreted legal grounds for abortion, requirements for third-party authorizations to receive abortion, mandatory waiting periods, requirements for medically unnecessary tests or procedures, restrictions on public funding and private insurance coverage, and requirements for the provision of misleading or inaccurate information may all be intended to discourage women from having an abortion $[2,6]$. In addition, unregulated conscientious objection opens the door for disingenuous claims of moral conscience for refusing care and compromises accountability for ensuring timely access to care. When combined, these and other barriers may exacerbate inequities to access and delays in seeking services, or serve as a deterrent to seeking legal services altogether, potentially increasing the likelihood of unsafe abortion.

Any barrier, including abuse of conscientious objection, potentially causes delays in gaining access to a needed health service. Legal abortion using WHO-recommended methods and practice is one of the safest of all medical procedures that women undergo. However, although the risk of mortality from safe abortion is low, the risk increases for each additional week of gestation. A study on legal abortion in the USA from 1988 to 1997 found that the overall risk of death from abortion was 0.7 per 100,000 legal abortions [7], with gestational age at time of abortion the greatest risk factor for abortion-related death. The mortality rate for abortions at a gestational age of 8 or fewer weeks was 0.1 , but for abortions at 21 or more weeks the rate was 8.9 , which was comparable to mortality associated with childbirth in the USA, between 1998 and 2005 [8].

Because conscientious objection is just one of a potentially large number of interconnected barriers to safe abortion services, it is difficult to evaluate the direct impact on access of disingenuous claims of conscientious objection, of conscientious objection without referral, and of refusal to treat emergencies. Indeed, the extent to which conscientious objection to abortion directly results in pregnancy-related mortality and morbidity is unknown and merits further investigation.

\section{Policy, health system, and service delivery interventions to protect women's health and their human rights}

UN treaty-monitoring bodies, and regional and national courts have increasingly called upon states to provide comprehensive sexual and reproductive health information and services to women and adolescents, to eliminate regulatory and administrative barriers that impede women's access to safe abortion services, and to provide treatment for abortion complications [9-33]. This requires states to train and equip health service providers, along with other measures to ensure that such abortion is safe and accessible [34]. Human rights bodies have also called upon states to ensure that the exercise of conscientious objection does not prevent individuals from obtaining services to which they are legally entitled $[17,18,26,35,36]$. When laws, policies, and programs do not take into consideration the multiple challenges inherent in implementing conscientious objection to abortion care, women's health and their human rights can be compromised. Specifically, there should be regulations for health service providers on how to invoke conscientious objection without jeopardizing women's access to safe, legal abortion services, especially with regard to referral and in emergency cases when referral is not possible.

In addition to providing guidance for regulating providers' conscientious objection to legal abortion, the WHO safe abortion document highlights a number of health system interventions that can facilitate equitable access to and availability of safe abortion [2]. As a first step, the provision and use of effective contraception can reduce the likelihood of unintended pregnancy and, thus, women's need for recourse to abortion. As a remedy to shortages of willing providers of legal abortion care, states should consider improving access through training mid-level providers and offering abortion services at the primary-care level and through outpatient services. Abortion care can be safely provided by any properly trained healthcare provider, including nurses, midwives, clinical officers, physician assistants, family welfare visitors, and others who are trained to provide basic clinical procedures related to reproductive health. Abortion care provided at the primary-care level and through outpatient services in higher-level settings can be done safely and minimizes costs while maximizing the convenience and timeliness of care for the woman. Allowing home use of misoprostol following provision of mifepristone at the healthcare facility can further improve the privacy, convenience, and acceptability of services, without compromising safety. Financing mechanisms can facilitate equitable access to good-quality services and, to the extent possible, abortion services should be mandated for coverage under insurance plans.

Governments have many options for facilitating good access to safe, legal abortion. Ultimately, to mitigate the potential impacts of conscientious objection, well-trained and equipped healthcare providers and affordable services should be readily available and within reach of the entire population. This is essential for ensuring access to safe abortion and should be both a public health and a human rights priority.

\section{Conflict of interest}

The authors have no conflicts of interest. B.R.J., M.V.D., and M.T. are staff members of WHO. The authors alone are responsible for the views expressed in the present article, which do not necessarily represent the decisions, policy, or views of WHO.

\section{References}

[1] WHO. Unsafe Abortion: Global and Regional Estimates of the Incidence of Unsafe Abortion and Associated Mortality in 2008. Sixth Edition. Geneva: WHO; 2011. 
[2] WHO. Safe Abortion: Technical and Policy Guidance for Health Systems. Second Edition. Geneva: WHO; 2012.

[3] International Covenant on Civil and Political Rights, Article 18. United Nations; entry into force 23 March 1976

[4] Verein Kontakt-Information-Therapie (KIT) and Hagen v. Austria, No. 11921/86 ECHR. (1988).

[5] Dressers R. Professionals, conformity and conscience. Hastings Cent Rep 2005;35:9-10.

[6] Guttmacher Institute. An Overview of Abortion Laws. State Policies in Brief. New York: Guttmacher Institute; 2013.

[7] Bartlett LA, Berg CJ, Shulman HB, Zane SB, Green CA, Whitehead S, et al. Risk factors for legal induced abortion-related mortality in the United States. Obstet Gynecol 2004;103(4):729-37.

[8] Raymond EG, Grimes DA. The comparative safety of legal induced abortion and childbirth in the United States. Obstet Gynecol 2012;119(2, Part 1):215-9.

[9] UN Human Rights Committee. General comment 28: equality of rights between men and women (Article 3). United Nations; 20 March 2000.

[10] UN Human Rights Committee. Concluding observations: Ecuador. United Nations; 18 August 1998.

[11] UN Human Rights Committee. Concluding observations: Guatemala. United Nations; 27 August 2001.

[12] UN Human Rights Committee. Concluding observations: Poland. United Nations; 2 December 2004.

[13] UN Human Rights Committee. Concluding observations: Madagascar. United Nations; 11 May 2007.

[14] UN Human Rights Committee. Concluding observations: Chile. United Nations; 18 May 2007.

[15] UN Human Rights Committee. Concluding observations: Colombia. United Nations; 26 May 2004.

[16] UN Human Rights Committee. Karen Noella Llantoy Huaman v. Peru, UN Doc. CCPR/C/85/D/1153/2003. United Nations; 2005.

[17] UN Committee on the Elimination of Discrimination against Women. Concluding observations: Columbia. United Nations; 5 February 1999.

[18] UN Committee on the Elimination of Discrimination against Women. Concluding observations: Nicaragua. United Nations; 2 February 2007.

[19] UN Committee on the Elimination of Discrimination against Women. Concluding observations: Brazil. United Nations; 10 August 2007.

[20] UN Committee on the Elimination of Discrimination against Women. Concluding observations: Nepal. United Nations; 24 September 2001.
[21] UN Committee on Economic, Social and Cultural Rights. Concluding observations: Costa Rica. United Nations; 22 April 2008.

[22] UN Committee on the Rights of the Child. Concluding observations: Chile. United Nations; 23 April 2007.

[23] African Commission on Human and Peoples' Rights. Protocol to the African Charter on Human and Peoples' Rights on the Rights of Women in Africa, Article 14.2. Maputo: African Commission on Human and Peoples' Rights; adopted 11 July 2003.

[24] UN Committee on Economic, Social and Cultural Rights. Concluding observations: Malta. United Nations; 4 December 2004.

[25] UN Committee on Economic, Social and Cultural Rights. Concluding observations: Monaco. United Nations; 13 June 2006.

[26] UN Committee on the Elimination of Discrimination against Women. General recommendation no. 24: Women and health (Article 12). United Nations; 1999.

[27] UN Committee on the Elimination of Discrimination against Women. Concluding comments: Dominican Republic. United Nations; 18 August 2004.

[28] UN Committee on Economic, Social and Cultural Rights. Concluding observations: Nepal. United Nations; 29 August 2001.

[29] UN Committee on Economic, Social and Cultural Rights. Concluding observations: Chile. United Nations; 1 December 2004.

[30] UN Committee on the Elimination of Discrimination against Women. Concluding observations: Sri Lanka. United Nations; 1 February 2002.

[31] UN Committee on the Elimination of Discrimination against Women. Concluding observations: Honduras. United Nations; 10 August 2007.

[32] UN Committee on the Elimination of Discrimination against Women. L.C. v. Peru, CEDAW/C/50/D/22/2009. United Nations; 4 November 2011.

[33] UN Committee on the Rights of the Child. Concluding observations: Chile. United Nations; 23 April 2007.

[34] Key actions for the further implementation of the Programme of Action of the International Conference on Population and Development, adopted by the twenty-first special session of the General Assembly, New York, 30 June-2 July 1999. New York, United Nations; 1999.

[35] UN Human Rights Committee. Concluding observations: Zambia. United Nations; 9 August 2007

[36] R.R. v. Poland, No. 27617/04 ECHR. (2011). 